Bangladesh J. Zool. 41(2): 217-228, 2013

\title{
AQUACULTURE PRACTICES IN TWO SEASONAL FLOODPLAINS OF BANGLADESH
}

\author{
Mahbuba Akter, Tahmina Afroz ${ }^{1}$ and Md. Ghulam Mustafa ${ }^{2}$ \\ Department of Zoology, Govt. Shahid Sohrawardi College, Dhaka, Bangladesh
}

\begin{abstract}
A comparative technical and economic analysis of two communitybased seasonal floodplains (Khirai and Angrail) of Daudkandi Upazila, Comilla during 2008 to 2010, are represented in this paper. The two floodplains differed mainly in management and fish production which were related to capital investment, variable cost, share of profits and proportional reimbursement to the fishers. Local management committees have been developed in each floodplain with significant differences. Average $142 \mathrm{~kg} / \mathrm{ha}$ of fish fingerlings (carps such as Catla catla, Labeo rohita, Cirrhinus cirrhosus, Labeo calbasu, Labeo bata and exotic species such as Hypopthalmicthys molitrix, Aristichthys nobilis, Cyprinus carpio, Ctenopharyngodon idella, Pungasius hypophthalmus, Barbonymus gonionotus, Oreochromis niloticus) were stocked at the varying proportions. Fish production obtained were 2.8 to $4.4 \mathrm{mt} / \mathrm{ha}$ and 1.1 to $1.3 \mathrm{mt} / \mathrm{ha}$ in Khirai and Angrail floodplain, respectively. The average cost of fish production, total income and the net income have been estimated as Tk. $209650 \pm 54167.12 /$ ha, Tk. $281306 \pm$ 88263.42/ha and Tk. $71656 \pm 35152.51 /$ ha in Khirai floodplain and Tk. $62349 \pm$ 5768.90/ha, Tk. $111930 \pm 12711.02 /$ ha and Tk. $49580 \pm 6948.26 /$ ha in Angrail floodplain, respectively. The benefit cost ratio (BCR) has been recorded as 1.33 and 1.79 in Khirai and Angrail floodplain, respectively. The results reveal that the fish production and economic benefit was higher in Khirai floodplain.
\end{abstract}

Key words: Floodplain aquaculture, benefit cost ratio, Bangladesh

\section{INTRODUCTION}

Fish and fisheries resources play a vital role in the socio-economic development of the country. The fisheries sector contributes about $60 \%$ of the national animal protein intake, $4.43 \%$ to GDP and $2.73 \%$ of the total foreign exchange earnings of Bangladesh (DOF, 2012).

Through a number of both backward and forward linkages, floodplain aquaculture projects have been contributing to the local economy of Daudkandi upazila of Comilla. The local economy can now employ more people and outmigration has been greatly reduced (Jahan, 2011). Therefore, this has gained from both the direct benefits of the projects (increased production, profits, incomes etc.) and from the indirect benefits that are transmitted through backward linkages, mainly from the supplier of inputs for the fish production.

${ }^{1}$ Department of Zoology, Jahangirnagar University, Savar, Dhaka, Bangladesh. ${ }^{2}$ Department of Fisheries, University of Dhaka, Dhaka-1000, Bangladesh. 
Four clearly identifiable groups of people such as, the stakeholder-land-owners, the permanent staff of the project, the new fishers who get the opportunity to harvest fish and involved in earthwork activities, have gained directly from the floodplain aquaculture (FPA) project (Toufique and Gregory 2008).

Mustafa and Brooks (2009) stated that the semi-closed water bodies the fish harvest increased from an annual average of $380 \mathrm{~kg} /$ ha in 2002 to $921 \mathrm{~kg} / \mathrm{ha}$ by 2005. The floodplain system tends to use comparatively more feed and fertilizers per unit area that pond-based aquaculture. According to DOF (2012), Bangladesh has extensive water bodies that have a high potential for fisheries production. Within the last 10 years, it has seen a remarkable increase in fish culture production from $786604 \mathrm{mt}$ (2001-2002) to $1460769 \mathrm{mt}$ (2010-2011), an average increase of $67417 \mathrm{mt}$ per annum.

Wetland ecosystems are providing a wide range of services. Considering the importance of seasonal floodplains in Bangladesh, a study has been planned to investigate the probability of exercising different technical intervention (fingerlings stocking, application of feed and fertilizer) in enhancement of fish production in the seasonal floodplains for the socio-economic improvement of the local communities.

The objective of the study was to assess the fish production performance and economic benefit gains through the aquaculture practices in Khirai and Angrail floodplains of Daudkandi under Comilla and Dhaka district, respectively.

\section{MATERIAL AND METHODS}

For the study of fishery two floodplains e.g. Khirai $\left(90^{\circ} 39^{\prime}\right.$ to $90^{\circ} 53^{\prime} \mathrm{E}$ and $23^{\circ} 25^{\circ}$ to $23^{\circ} 38^{\circ} \mathrm{N}$ ) and Angrail $90^{\circ} 11^{\prime}$ to $90^{\circ} 21^{\circ} \mathrm{E}$ and $22^{\circ} 44^{\circ}$ to $24^{\circ} 02^{\prime} \mathrm{N}$ floodplains were selected from the Meghna and Turag river basin which located in Comilla and Dhaka district, respectively. Mainly, the nature of connectivity with the river basin, the physiographic similarities and the community response towards effective utilization of the floodplain fishery were measured to select those floodplains as research sites. Khirai floodplain was treated as a proper model of floodplain fishery by Department of Fisheries (DOF) and Angrail floodplain privately owned by some beneficiaries of surrounding people. The management practices also were different for fish culture in two floodplains.

For the present study, survey was conducted by using structural format. Repeated visits (two times per month) were made to collect data in the study area both from each floodplain individually. For selecting the appropriate beneficiaries, a list of the resource users were also prepared and later on verified. Floodplain Management Committee (FMC) was formed by the beneficiaries. A questionnaire was followed and the formal and informal data 
was collected by a field survey that was conducted for three years from March, 2008 to February, 2011. At the time of interview the researchers asked questions systematically and explained whenever it was felt necessary. Data was mainly collected from official records of the individual floodplains and from beneficiaries who were direct involved in aquaculture. Data also verified by discussing with local peoples and also with the authority of SHISUK (Shikkha Shastha Unnayan Karzakram), a local NGO of Daudkandi, Comilla and with the upazila Fisheries Officer of Savar upazila, Dhaka.

All the data were processed for analysis by transferring to a master sheet and computed with a view to facilitation tabulation. The tabulated data were then analyzed and condensed by using range, hectarage, average, percentage etc. This analysis was mainly followed in analyzing the collected information to assess the effect of using inputs and other related factors of floodplain fish culture. Final profitability of floodplain fish production was determined on the gross margin and net return analysis by using ANOVA method with SPSS (statistical package for social sciences) programme. In the study area for fish production the following inputs namely fertilizer, feeds, lime, fish fingerlings, human labor and miscellaneous costs were engaged which were considered as a priority advisory variables and those advisory variables were responsible for producing fish.

\section{RESULTS AND DISCUSSION}

The results of fish production and economic profitability of analysis conducted on collected data for three years from March, 2008 to February, 2011 in Khirai and Angrail floodplains are shown in Table 3 and Table 4.

Stocking for fish production: In Khirai and Angrail floodplains community based fish culture was started at first in 2004 and 2005, respectively. About twelve (12) fish of carp (Catla catla, Labeo rohita, Cirrhinus cirrhosus, Labeo calbasu, Labeo bata) and exotic species (Hypopthalmicthys molitrix, Aristichthys nobilis, Barbonymus gonionotus, Cyprinus carpio, Ctenopharyngodon idella, Pungasius hypophthalmus, Oreochromis niloticus) and exotic species were stocked and the production of fishes were estimated from the catch assessment structured data collected from two floodplains during 2008, 2009 and 2010 where the data of 2008 were used as the baseline data at the research period. In Khirai floodplain fish fingerlings of different species were stocked mainly from their own nursery ponds and a few portion bought from local sources. In Angrail floodplain, spawns were mainly collected from various fish hatchery and rare up to fingerling in the ponds. Table 1 reflects the stocking and harvesting record of the studied floodplains. 
Table 1. Stocking and harvesting quantity of stocked fishes in Khirai and Angrail floodplains from 2008-2010

\begin{tabular}{|c|c|c|c|c|}
\hline Floodplain & Year & $\begin{array}{l}\text { Stocking quantity } \\
(\mathrm{kg} / \mathrm{ha})\end{array}$ & $\begin{array}{l}\text { Harvesting quantity } \\
(\mathrm{kg} / \mathrm{ha})\end{array}$ & Survival rate $(\%)$ \\
\hline \multirow[t]{3}{*}{ Khirai } & 2008 & 185 & 2568 & 51 \\
\hline & 2009 & 159 & 2770 & 57 \\
\hline & 2010 & 192 & 4117 & 65 \\
\hline \multirow[t]{3}{*}{ Angrail } & 2008 & 100 & 1043 & 47 \\
\hline & 2009 & 109 & 1119 & 50 \\
\hline & 2010 & 105 & 1176 & 51 \\
\hline Average & & 141.66 & 2132.17 & 53.5 \\
\hline
\end{tabular}

To ensure better survival and rapid growth, comparatively larger fingerlings were stocked in these floodplains. The stocking density in Khirai floodplain during 2008, 2009 and 2010 were 185, 159 and $192 \mathrm{~kg} / \mathrm{ha} / \mathrm{yr}$, respectively; and in Angrail floodplain the stocking density were 100, 109 and $105 \mathrm{~kg} / \mathrm{ha} / \mathrm{yr}$ during 2008, 2009 and 2010, respectively. All species were stocked in varying proportion at the rate of $142 \mathrm{~kg} / \mathrm{ha} / \mathrm{yr}$ (Table 1). Mainly variations in stocking combinations and stocking densities in different years of intervention largely depended on their growth performance and on the availability of fingerlings as well as on the market price and also consumer's preference. According to Ahmed (1997), the technical basis of the stocking programme rests on proper utilization of the underutilized nutrients and fish food produced in the floodplains during the flood season which enhance the total production of the floodplain fisheries. The scientific management such as the practice of appropriate fish stocking program, adoption of culture-based fisheries and rehabilitation of available floodplain fish habitats and conservation of fish stocks may have to increase the fish production from floodplains. The survival rate was more or less same in both of two cultured floodplains and the average survival rate was $53.5 \%$. Ahmed (1999) estimated that the average survival rate of stocked fishes in the seasonal floodplains was found to be $46.22 \pm 2.12 \%$ although some variations were noted among different species of fishes in different seasonal floodplains due to handling stress in carrying and escapement during the onset of flood and the survival rate of stocked fishes is much higher than the survival rate of stocked fishes in second aquaculture project (SADP) to be $25 \%$ in the seasonal floodplains. On the other hand, Islam (1999) reported that survival rate of stocked fishes in the third fisheries project was $15 \%$.

Use of feed and fertilizer: Food and fertilizer used in Khirai floodplain were higher than the Angrail floodplain in amount. In Khirai floodplain, the amount of food and fertilizer used in the year 2010 were more than double than the 
baseline year, whereas these amounts were slightly higher in the last year than the baseline year in Angrail floodplain (Fig. 1).

Usually, fish farmers in Bangladesh use inputs like feed, fertilizer and lime in prescribed dose. In Angrail floodplain fishers used those inputs in approved doses but, in Khirai floodplain fish farmers were seen using those inputs in sufficient doses. The average quantity of total feed used in Khirai floodplain was $14931 \mathrm{~kg} / \mathrm{ha}$ and in Angrail floodplain was $4295 \mathrm{~kg} / \mathrm{ha}$. The fertilizers (Urea, TSP and cow-dung) used $9188 \mathrm{~kg} / \mathrm{ha}$ in Khirai floodplain whereas in Angrail floodplain those were $2649 \mathrm{~kg} / \mathrm{ha}$, respectively.

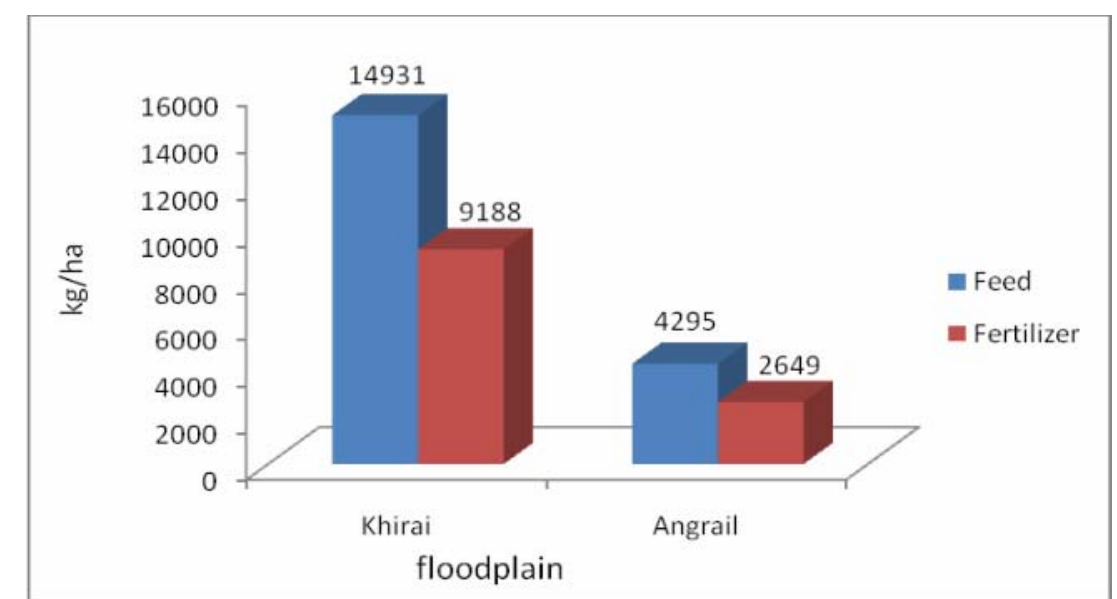

Fig. 1. Using trends of food and fertilizer ( $\mathrm{kg} / \mathrm{ha}$ on average) in cultured floodplains

Fish production: The relatively large sized stocked fishes have been harvested gradually from the seasonal floodplains appeared to be advantageous in term of financial gain. The younger fish has been allowed to grow, feed and take benefit of available free space under less competitive environment by the successive removal of larger fishes. The harvesting strategies should be set based on the flood duration, water levels and its turn down pattern, and for sequential harvesting over a longer period of time aiming at promotion of higher growth rate of fish and maximizing economic return (Dey and Prein 2005).

The contribution of the exotic species to the total aquaculture yield of the cultured floodplains ranged from $58.01 \%$ to $82.91 \%$ indicating their superiority over their carps counterparts. The performances of the exotic species were very remarkable (81.63 \%) in Khirai floodplain and in Angrail floodplain (59.28\%) these were lower than Khirai floodplain. In Khirai floodplain, the contribution of exotic species tilapia was the highest (36.40\%), followed by silver carp (16.89\%). 
Among the carp species, rohu and mrigal showed a modest contribution $(6.13 \%$ and $8.03 \%)$ while catla $(3.07 \%)$, bata $(0.63 \%)$ and kalibaus $(0.18 \%)$ contributed very little to the total fish yield. In Angrail floodplain tilapia (17.89\%) and silver carp $(12.28 \%)$ contributed mass of the total yield of the stocked fish. The exotic species all together contributed about $59.28 \%$ to the total yield, while the carps species, rohu contributed $13.71 \%$ to the total yield followed by catla $(10.65 \%)$, bata $(7.91 \%)$, mrigal $(6.29 \%)$ and kalibaus $(2.15 \%)$. The combination (\%) of the stocked species is given in Table 2 .

The proportional analysis of the fish production in the cultured seasonal floodplains in 2009 and 2010 showed significant ( $p$ 0.05) variations in terms of production of stocked and non-stocked fish (Table 3). Due to management strategies the production level in Khirai floodplain increased significantly (p 0.05) over the baseline record. In Angrail the production level was also increased from the baseline. Due to initiation of community-based fish culture program though the community involvement was very limited in Angrail floodplain the fish production have got profitability.

Table 2. Contribution (\%) of the stocked species to the total stocked fish production in two floodplains

\begin{tabular}{lllllllcc}
\hline Name of fish species & \multicolumn{4}{c}{ Khirai floodplain \% } & \multicolumn{4}{c}{ Angrail floodplain \% } \\
\cline { 2 - 9 } & 2008 & 2009 & 2010 & Ave.* & 2008 & 2009 & 2010 & Ave.* $^{*}$ \\
\hline Catla catla & 2.65 & 3.29 & 3.28 & 3.07 & 10.16 & 9.65 & 12.15 & 10.65 \\
Labeo rohita & 4.05 & 6.90 & 7.43 & 6.13 & 13.71 & 13.40 & 14.03 & 13.71 \\
Cirrhinus cirrhosus & 9.93 & 9.42 & 4.74 & 8.03 & 5.27 & 7.06 & 6.55 & 6.29 \\
Labeo calbasu & 0.27 & 0.14 & 1.14 & 0.18 & 2.01 & 2.23 & 2.21 & 2.15 \\
Labeo bata & 0.19 & 0.65 & 1.04 & 0.63 & 8.54 & 9.65 & 5.53 & 7.91 \\
Total (carps) & $\mathbf{1 7 . 0 9}$ & $\mathbf{2 0 . 4}$ & $\mathbf{1 7 . 6 3}$ & $\mathbf{1 8 . 3 7}$ & 39.69 & $\mathbf{4 1 . 9 9}$ & $\mathbf{4 0 . 4 7}$ & $\mathbf{4 0 . 7 2}$ \\
Oreochromis niloticus & 34.62 & 32.64 & 41.95 & 36.40 & 18.31 & 17.33 & 18.03 & 17.89 \\
Hypopthalmichthys molitrixyyyyyyyyyyyyyyy & 16.12 & 17.11 & 17.44 & 16.89 & 12.37 & 11.88 & 12.59 & 12.28 \\
Aristichthys nobilis & 8.29 & 11.55 & 6.48 & 8.77 & 10.17 & 9.12 & 10.63 & 9.97 \\
Cyprinus carpio & 7.52 & 7.87 & 4.66 & 6.68 & 4.60 & 7.06 & 6.46 & 6.04 \\
Ctenopharyngodon idella & 1.67 & 5.74 & 5.76 & 4.39 & 4.51 & 4.39 & 4.51 & 4.47 \\
Barbonymus gonionotus & 6.82 & 1.34 & 2.19 & 3.45 & 5.56 & 4.83 & 4.93 & 5.11 \\
Pungasius hypophthalmus & 7.87 & 3.35 & 3.89 & 5.04 & 4.79 & 3.40 & 2.38 & 3.52 \\
Total (exotic species) & $\mathbf{8 2 . 9 1}$ & $\mathbf{7 9 . 6 0}$ & $\mathbf{8 2 . 3 7}$ & $\mathbf{8 1 . 6 3}$ & $\mathbf{6 0 . 3 1}$ & $\mathbf{5 8 . 0 1}$ & $\mathbf{5 9 . 5 3}$ & $\mathbf{5 9 . 2 8}$ \\
\hline
\end{tabular}

*Ave. =Average

Fish production showed amazing increase in Khirai floodplain, due to planned stocking over the baseline production. Baseline fish production in this floodplain was $2787 \mathrm{~kg} / \mathrm{ha} / \mathrm{yr}$ which stood at $4366 \mathrm{~kg} / \mathrm{ha} / \mathrm{yr}$ in 2010 indicating double increase. Further remarkable increased in fish production of both stocked $4117 \mathrm{~kg} / \mathrm{ha} / \mathrm{yr}$ and non-stocked $249 \mathrm{~kg} / \mathrm{ha} / \mathrm{yr}$ in 2010 in Khirai floodplain, might be due to earlier stocking of moderate size over wintering 
fingerlings and proper technological management under the community based fisheries initiatives. During 2009 and 2010, fish production was comparatively lower $(1217 \mathrm{~kg} / \mathrm{ha} / \mathrm{yr}$ and $1266 \mathrm{~kg} / \mathrm{ha} / \mathrm{yr})$ in Angrail floodplain as compared to Khirai floodplain. In 2008, baseline fish production was $1158 \mathrm{~kg} /$ ha which was also lower than one and half from baseline production of Khirai floodplain. The production figure of both cultured and non-cultured is placed in Table 3.

Table 3. Production of stocked and non-stocked fish from the selected floodplains during 2008-2010

\begin{tabular}{lcccccc}
\hline Floodplain & $\begin{array}{c}\text { Area } \\
\text { (ha) }\end{array}$ & Year & $\begin{array}{c}\text { Stocked fish } \\
\text { (kg/ha/yr) }\end{array}$ & $\begin{array}{c}\text { Non-stocked } \\
\text { fish }(\mathrm{kg} / \mathrm{ha} / \mathrm{yr})\end{array}$ & $\begin{array}{c}\text { Total fish } \\
(\mathrm{kg} / \mathrm{ha} / \mathrm{yr})\end{array}$ & $\begin{array}{c}\text { Total fish } \\
(\mathrm{MT} / \mathrm{ha} / \mathrm{yr})\end{array}$ \\
\hline \multirow{3}{*}{ Khirai } & 61 & $2008^{*}$ & 2568 & 219 & 2787 & 2.8 \\
& & 2009 & 2770 & 139 & 2909 & 2.9 \\
& & 2010 & 4117 & 249 & 4366 & 4.4 \\
Angrail & 35 & $2008^{*}$ & 1043 & 115 & 1158 & 1.1 \\
& & 2010 & 1176 & 98 & 1217 & 1.2 \\
& & & 90 & 1266 & 1.3 \\
\hline
\end{tabular}

*Indicates baseline year.

The mean fish production as achieved from the floodplains under the project is higher than the national average of $284 \mathrm{~kg} / \mathrm{ha}$ from the floodplains (DOF 2012). This is fundamentally due to the implications of community-based management practices including technical interventions of fish culture in the floodplains. It is also reported that if the stocking programme is properly introduced, it is expected to result in an incremental yield of $300 \mathrm{~kg} / \mathrm{ha}$ in the major floodplains and $700 \mathrm{~kg} / \mathrm{ha}$ in minor floodplains against the present low level of productions of $70-100 \mathrm{~kg} / \mathrm{ha}$ (Ali and Fisher 1995).

Fish production in the Khirai and Angrail seasonal floodplains exhibited 1 to 2 folds increase over the baseline production level. Similar level of increase in fish yield was reported by Rahman et al. (1999) from floodplains following intervention. Islam (1999) noted that excellent growth performances of common carp in seasonal floodplains which was agreed with the present study. Therefore it may be concluded that exotic species such as tilapia, silver carp, bighead carp and common carp could be the preferable species for stocking in the seasonal floodplain aquaculture because of their fast growth rate, high adaptability and consumer's acceptance.

Dey et al. (2005) reported that fish production can increase by about 600 $\mathrm{kg} / \mathrm{ha} /$ year in shallow flooded areas and upto $1.5 \mathrm{t} / \mathrm{ha} / \mathrm{year}$ in deep-flooded areas, without a reduction in the rice yield or wild fish catch through community-based fish culture in rice fields. Although the fish production from 
inland water increased but the total production from floodplains and beels decreased from $63 \%$ to $46 \%$ (DOF 2006). According to Bayley (1988) the maximum potential yields is more highly exploited tropical floodplains at 110$160 \mathrm{~kg} / \mathrm{ha} / \mathrm{yr}$. Most of the floodplains in Bangladesh are not cultured in a plan way as like as Daudkandi area floodplain shown by recent research (Chandra et al. 2010).

Marketing of fish: Project management of the floodplain had developed good marketing network among 'Aratders' from different fish landing centers of Chittagong, Sylhet, Feni, Manikganj and Dhaka. There were some variations in the marketing process of the stocked fishes. In case of Khirai floodplain the local fish traders who sell fish from door to door, purchased the stocked fish at the farm gate. Maximum quantities of stocked and non-stocked fishes were sold to the local wholesale markets. The beneficiaries were involved in the marketing procedure of the harvested fishes. In case of Angrail floodplain, the total harvested fishes were partly disposed of to the local consumers, and maximally to the 'Paikers' who transported it to the nearest and distant market place. Harvested fish was left couple of hours without ice and handled roughly during sorting and weighing before they were loaded in truck or rickshaw van.

Total cost of fish production: The cost items such as dyke/culvert construction and/ or repair, use of inputs (includes cost of feed and fertilizers with lime, office set up) and miscellaneous (depreciation of assets, boat/deep machine purchase and loan interest) are mentioned in Table 4 for the costs of fish production. The amount and contribution (\%) of different cost items to the total cost has been illustrated. A minimum cost for the maintenance of dyke/culvert was Tk. 3389.82/ha on average which was $1.62 \%$ of the total investment for fish culture purposes in Khirai floodplain whereas it was $3.45 \%$ in Angrail floodplain. According to Chandra et al. (2010), as the floodplain area had lower land elevation, it became flooded regularly depending on the water level in the adjacent rivers. For aquaculture project to select floodplain area, it required encircling the area by constructing good embankment and sluice gates. Such construction of common infra structure happens to be very expensive in low-lying areas and often impossible for the community. The average amount of cost for both nursery and land lease was found Tk. 8983.28/ha and $4.28 \%$ of the total investment in Khirai floodplain while it was Tk. 5904.77/ ha and 9.47\% of the total investment in Angrail floodplain.

For stocking the fish fingerlings (demand larger sized species e.g., Catla catla, Labeo rohita, Hypopthalmicthys molitrix, Aristichthys nobilis, Cyprinus carpio, Ctenopharyngodon idella, Pungasius hypophthalmus) the cost was found to be Tk. $21880.80 /$ ha on average which was $10.44 \%$ in Khirai floodplain and 
Tk. $12145.74 /$ ha on average which was $19.48 \%$ of the total investment in Angrail floodplain. Average input for feed and fertilizer was Tk.120176.46/ha $(57.32 \%)$ in Khirai floodplain and Tk. 29867.11/ha (47.90\%) in of the total investment in Angrail floodplain.

Office management included various items such as office set up, purchase of furniture, decoration, electric bill, mobile cost, pen and papers etc. The cost of office management in Khirai floodplain was very high, as the floodplain is a place of mass gathers and meetings and discussions are especially common than that of Angrail floodplain. All the records of the past and present were kept in Khirai floodplain office which was well-established whereas, no such established office was present in Angrail floodplain and here it must be needed to develop. From the study it was found that the average cost of office management was Tk. 17336.90/ha, which contributed $8.27 \%$ in Khirai floodplain and Tk. 1740.97/ha, which contributed $2.79 \%$ in Angrail floodplain. The committee members were honored by additional money after calculating the final costbenefit of the year. They were responsible for the welfare of the project so the shareholders offered them that money willingly in Khirai floodplain.

The fish harvesting costs were Tk. 8179.25/ ha which contributed $3.90 \%$ to total cost at Khirai and 3152.37/ha which contributed $5.06 \%$ to total cost at Angrail floodplain. The fish was marketed in the far-away places such as Chittagong, Sylhet, Feni and Dhaka for Khirai floodplain and Savar, Manikganj and Dhaka for Angrail floodplain so it required high amount of money. The wholesaler and the 'Aratdars' who came during the fish tender at fish landing center were entertained that increased the total cost (Table 4). The marketing cost of fish was found Tk. 15195.20/ha on average which contributed $7.25 \%$ in Khirai floodplain and Tk. 1728.17 / ha on average which contributed $2.77 \%$ to the total cost in Angrail floodplain. The miscellaneous cost included the items such as social development, donation for Madrasha, Mosques, deep tube wells, guest entertainment, depreciation of assets etc. was Tk. 14508.08/ha on average and it contributed $6.92 \%$ to the total cost at Khirai floodplain and Tk. 5662.74/ha and contributed $9.08 \%$ to the total cost at Angrail floodplain (Table 4).

The average of total income from fish production of the floodplains was Tk. $281306 /$ ha with a net income Tk. $71656 /$ ha in Khirai floodplain and Tk. 111930/ha with a net income Tk. 49580/ha two seasonal culture-based floodplains. The average benefit cost ratio (BCR) for Khirai floodplain was 1.33 and for Angrail floodplain it was 1.79, respectively, which indicate that fish culture in seasonal floodplains is profitable under the present set of management practices. Fish culture in managed seasonal floodplains appeared 
to be biologically and economically feasible. In the managed seasonal floodplains social benefits of community based fish culture program are of diversified in nature, spaced out from economic considerations. The cast off and unutilized water bodies were turned into prolific resources which generated part time employment, enhanced food and animal protein intake and built up awareness among the community peoples in helping of utilization of the common limited resources. The costs, and returned of fish cultured in two floodplains is presented in Table 4.

Table 4. Depiction of average total costs and returns of fish culture in two floodplains

\begin{tabular}{|c|c|c|c|c|}
\hline Cost items & $\begin{array}{c}\text { Amount (Tk/ha/year) } \\
\text { in Khirai }\end{array}$ & $\begin{array}{c}\% \text { of the } \\
\text { total } \\
\text { cost }\end{array}$ & $\begin{array}{c}\text { Amount } \\
\text { (Tk/ha/year) in } \\
\text { Angrail }\end{array}$ & $\begin{array}{l}\% \text { of the } \\
\text { total cost }\end{array}$ \\
\hline $\begin{array}{l}\text { Maintenance of } \\
\text { dyke/culvert }\end{array}$ & $3389.82 \pm 699.79$ & 1.62 & $2147.60 \pm 219.93$ & 3.45 \\
\hline Nursery and land lease & $8983.28 \pm 2645.09$ & 4.28 & $5904.77 \pm 329.91$ & 9.47 \\
\hline Fish Fingerlings & $21880.80 \pm 4666.50$ & 10.44 & $12145.74 \pm 932.28$ & 19.48 \\
\hline Feed and fertilizer & $120176.46 \pm 49268.57$ & 57.32 & $29867.11 \pm 4974.73$ & 47.90 \\
\hline Office management & $17336.90 \pm 3316.96$ & 8.27 & $1740.95 \pm 128.46$ & 2.79 \\
\hline Harvesting & $8179.25 \pm 2309.89$ & 3.90 & $3152.37 \pm 121.52$ & 5.06 \\
\hline Marketing & $15195.20 \pm 6491.57$ & 7.25 & $1728.17 \pm 35.75$ & 2.77 \\
\hline Miscellaneous & $14508.08 \pm 1498.78$ & 6.92 & $5662.74 \pm 492.49$ & 9.08 \\
\hline Total cost (TC) & $209650 \pm 54167.12$ & 100 & $62349 \pm 5768.90$ & 100 \\
\hline Total income(TI) & $281306 \pm 88263.42$ & & $111930 \pm 12711.02$ & \\
\hline Net income (TI-TC) & $71656 \pm 35152.51$ & & $49580 \pm 6948.26$ & \\
\hline $\mathrm{BCR}(\mathrm{TI} / \mathrm{TC})$ & 1.33 & & 1.79 & \\
\hline
\end{tabular}

This study provides a clear picture on impact of fisheries management practice in terms of fish production in selected two floodplains. It revealed that the total fish production in Khirai floodplain is distinctively higher than the fish production of Angrail floodplain due to introduction of better management practice. It also indicated that the introduction of better management tools such as stocking of good quality fingerlings, use of fish feed and fertilizer; and allowing them to grow at marketable size influenced the fish production of Khirai floodplain. Another important reason for higher fish production in Khirai floodplain might be the involvement of community people in fisheries management plan. The less fish production in Angrail floodplain indicated the stocking of different sized fingerlings (mixed with under sized fingerlings), no use of artificial fish feed. The contribution of exotic carps was higher than the native major carps. The result suggests that stocking of good quality fingerlings, use of quality fish feeds and fertilizers; and involvement of community people in floodplain fisheries activities enhance the fish production of the floodplains. This study also emphasizes the necessity of bringing all 
floodplains of Bangladesh under community based culture management practice to augment the fish production in view of fulfill the protein demand of the country and generate employment opportunity for the rural poor people of Bangladesh.

Acknowledgements: National Science, Information and Communication Technology (NSICT) supported this study appropriately. The authors also acknowledged thankfully for the facilities which provided by the Department of Fisheries (DOF) and the SHISHUK Office, a NGO OF Daudkandi Upazila, Comilla.

\section{LITERATURE CITED}

AHMED, N. 1997. Marketing of fish from selected floodplains in Bangladesh. In: Tsai, C. and Ali, M.Y. (eds.) Open water Fisheries of Bangladesh, Dhaka. The University Press Ltd. Dhaka. pp. 115-124.

AHMED, M.N. 1999. Fingerling stocking in open waters. In: Middendorp, H.A.J., Thompson, P.M. and Pomeroy, R. S. (eds.) Sustainable inland fisheries management in Bangladesh. ICLARM Conf. Proc. 58. pp. 201-208.

ALI, M.L. and FISHER, K. 1995. Potential, constraints and strategies for conservation and management of inland open water fisheries in Bangladesh. Report of the National Workshop on Fisheries Resources Development and Management in Bangladesh. Ministry of Fisheries and Livestock, Bangladesh. Dhaka, Bangladesh. pp. 2-25.

BAYLEY, P.B. 1988. Factors affecting growth rates of young flood-plain fishes: Seasonality and density dependence. Envir. Biol. Fish. 21: 127-147.

CHANDRA, K.J., SARKER, D., KHALEQUE, M.A. and DAS, D.R. 2010. Economic analysis of floodplain aquaculture at Daudkandi upazila in Comilla. J. Bangladesh Agril. Univ. 8(2): 323332.

DEY, M.M. and PREIN, M. 2005. Increased income from seasonally flooded rice fields through community based fish culture in Bangladesh and Vietnam. Plant Production Science. 8: 349353.

DEY, M.M. PREIN, M., HAQUE, A.B.M.M., SUlTANA, P., DAN, N.C. and HAO, N.V. 2005. Economic feasibility of community-based fish culture in seasonally flooded rice fields in Bangladesh and Vietnam. Aquaculture Economics and Management. 9(1 and 2): 65-88.

DOF (Department of Fisheries) 2006. Fish Catch Statistics of Bangladesh. Department of Fisheries. Bangladesh.

DOF (Department of Fisheries) 2012. Fishery statistical yearbook of Bangladesh 2010-2011. Fisheries Resources Survey System (FRSS), Department of Fisheries, Bangladesh. 46 pp.

ISLAM, M.Z. 1999. Enhancement of floodplain fisheries: experience of the Third Fisheries Project. In: Middendorp, H.A.J., Thompson, P.M. and Pomeroy, R.S. (eds.) Sustainable inland fisheries management in Bangladesh. ICLARM Conf. Proc. 58. pp. 209-218.

JAHAN, I. 2011. Fish diversity of Hamil beel and its management functions for sustainable production. PhD. Thesis. University of Dhaka. Bangladesh. 233 pp. 
MUSTAFA, M.G. and BROOKS, A.C. 2009. A comparative study of two seasonal floodplain aquaculture systems in Bangladesh Water policy 11, Supplement I (2009). pp. 69-79.

RAHMAN, M., CAPRISTRANO, D.A., MINKIN, S.F., ISLAM, A. and HALDER, S. 1999. Experience of community managed wetland habitat restoration. In: Middendorp, H.A. J., Thompson, P.M. and Pomeroy, R.S. (eds.). Sustainable inland fisheries management in Bangladesh. ICLARM Conf. Proc. 58. pp. 111-121.

TOUFIQUE, K.A. and GREGORY, R. 2008. Common waters and private lands: Distributional impacts of floodplain aquaculture in Bangladesh. Food Policy. 33: 587-594.

(Manuscript received on 9 February 2013; revised on 6 October 2013) 